\title{
Cockle Cerastoderma edule population mortality: role of the digenean parasite Himasthla quissetensis
}

\author{
Céline Desclaux*, Xavier de Montaudouin, Guy Bachelet \\ Laboratoire d'Océanographie Biologique, UMR 5805 CNRS, Université Bordeaux 1, 2 rue du Professeur Jolyet, \\ 33120 Arcachon, France
}

\begin{abstract}
Infection patterns of the digenean trematode Himasthla quissetensis in its second intermediate host, the edible cockle Cerastoderma edule, and the impact of this parasite on cockle populations were quantified. A 2 yr transplant experiment and a 4 yr survey were conducted in Arcachon Bay, a coastal lagoon on the Atlantic SW coast of France. Cockles free of H. quissetensis were transplanted at La Canelette, a station where cockles were usually highly infected. Infection began in May, when the water temperature reached $17^{\circ} \mathrm{C}$ and stopped in November $\left(12^{\circ} \mathrm{C}\right)$. There was no new infection between November and April. Monthly surveys at 2 stations, Arguin and La Canelette, confirmed that cockle infection by $H$. quissetensis occurred during the warmer period of the year. Only cockles with a shell length $>8 \mathrm{~mm}$ became infected; therefore, cockle growth rate, which differed at the 2 stations, was also a key factor explaining infection phenology. In winter, the mean parasite abundance of $H$. quissetensis in cockles decreased at both stations. The mortality rate of parasites in cockles was very low, with no seasonal pattern, and did not explain this winter decrease. Consequently, the decrease of $H$. quissetensis was interpreted as mortality of heavily infected cockles. At Arguin, where the cockle population was characterised by moderate abundance, high growth rate and short lifespan, cockle mortality amounted to $93 \%$ during the first year of benthic life, with no significant contribution of parasites; in the following year (Year 2), cockle mortality was $85 \%$, with $28 \%$ due to $H$. quissetensis infection. At La Canelette, the cockle population, characterised by low abundance and low growth rate, suffered almost $100 \%$ mortality in the first year, with no contribution by parasites, which started to infect cockles in the second year only; the remaining cockles had a long lifespan (up to $5 \mathrm{yr}$ ), and $>46 \%$ of their mortality was linked to $H$. quissetensis infection. It is concluded that both host growth rate and water temperature are important factors in the initiation of parasite infection and that the intensity of infection and its effect on host mortality closely depend on host growth and environmental factors.
\end{abstract}

KEY WORDS: Parasite-induced mortality · Population dynamics · Digeneans · Bivalves · Cockles

\section{INTRODUCTION}

Among the biotic factors that govern population dynamics of marine benthic invertebrates, parasitism has received relatively little attention (Mouritsen \& Jensen 1997, Desclaux et al. 2002). Digenean trematodes, however, are dominant macroparasites of bivalves and gastropods in marine ecosystems (Lauckner 1984b, de Montaudouin et al. 2000, Desclaux et al. 2002). They can have detrimental effects on the physi- ology (Jensen et al. 1999) and behaviour of their host (Holmes \& Bethel 1972, Moore \& Gotelli 1990, Combes 1991, Poulin 1995). The ultimate result can be host death (Deltreil \& His 1970, Jonsson \& André 1992), but there is generally a lack of data supporting digenean direct impacts at a population scale. Some species may cause severe tissue damage and mortalities when they occur at high intensities in their host, e.g. Monorchis parvus (= Cercaria cerastodermae I) (Jonsson \& André 1992) and Labratrema minimus (Hancock \& Urquhart 
1965, Deltreil \& His 1970) in Cerastoderma edule. Generally, trematodes that are the most pathogenic to bivalves are the species that utilise their host for asexual reproduction (Bower 1992). In molluscs, larval stages such as metacercariae are clearly deleterious (Holmes \& Bethel 1972) and induce mortalities on juvenile cockles or during epizootic events on commercially important bivalves (Lauckner 1983, 1987). Host mortalities have also been observed experimentally in gastropods infested with echinostomatid metacercariae, during the first $4 \mathrm{~d}$ after infection (Fried et al. 1995). However, some metacercariae seem to be energetically inert and cause little or no immediate physiological or behavioural response in the host, even when they are present at high numbers (Lauckner 1983).

Studies of parasite-induced mortality in molluscan hosts have shown how encysted parasites (trophically transmitted) may modify the intermediate host's behaviour (Bartoli 1976, Lauckner 1983, 1984a, Poulin et al. 1998), thereby increasing the intermediate host's probability of being eaten by the final host (Holmes \& Bethel 1972, Moore \& Gotelli 1990). Such a phenomenon (i.e. indirect mortality by 'favourization'; Combes 2001) involving Himasthla quissetensis has been studied recently with Cerastoderma edule in Arcachon Bay by Desclaux et al. (2002), who demonstrated that $H$. quissetensis could be involved in 2 to $8 \%$ of adult cockle mortality. Combes (2001) considered that favourization was any adaptive process used by a parasite to increase the probability of infesting the host.

Digeneans rarely leave any scar on the host shell (Bartoli 1976), thus preventing inference of their role in host mortality events. Anderson \& Gordon (1982) and Kennedy (1984) suggested that it would be useful to study the metacercarial digenean stages in hosts to detect parasite-induced host mortality. This can be done by monitoring either the variance to mean ratio of parasite abundance (Anderson \& Gordon 1982, Kennedy 1984 ) or the mean abundance or prevalence of metacercariae in host cohorts (Lester 1984, de Montaudouin et al. 2003). However, the decrease of these indices may result from emigration of parasitized animals, recruitment or immigration of unparasitized animals, metacercariae death, or death of the most infected individuals in the host cohort (Anderson \& Gordon 1982, Kennedy 1984, Wilson et al. 2002). A decrease of parasite abundance due to mortality can also be balanced by an infection event, and the final result will consequently be misinterpreted. It is therefore necessary to acquire a good knowledge of infection kinetics.

The present study consisted of 2 parts: (1) the period of infection was precisely identified through a transplant experiment of unparasitized cockles to a site where infection naturally occurred; (2) knowing infection patterns, a 4 yr monitoring programme of 2 cockle populations and their Himasthla quissetensis burden allowed us to demonstrate whether or not these parasites were involved in host mortality.

\section{MATERIALS AND METHODS}

Study area. This study was conducted in Arcachon Bay $\left(44^{\circ} 40^{\prime} \mathrm{N}, 1^{\circ} 10^{\prime} \mathrm{W}\right)$, a $156 \mathrm{~km}^{2}$ macrotidal lagoon on the SW Atlantic coast of France (Fig. 1). This shallow lagoon is characterised by semi-diurnal tides (maximum tidal range $4.35 \mathrm{~m}$ ). Important water exchange occurs with the ocean through the SW entrance of the lagoon and estimated at $370 \times 10^{6} \mathrm{~m}^{3}$ for an average spring tide and $130 \times 10^{6} \mathrm{~m}^{3}$ for a neap tide. Freshwater inputs are essentially due to the Leyre River (SE of the lagoon ), with $660 \times 10^{6} \mathrm{~m}^{3} \mathrm{yr}^{-1}$ (Bouchet 1968).

The first study site (Arguin) was a sandy bank situated in the most oceanic part of the lagoon, where salinity remains high year-round (32 to $35 \mathrm{psu}$ ) (Auby et al. 1999). Mean surface water temperature usually fluctuates between $7^{\circ} \mathrm{C}$ in winter and $23^{\circ} \mathrm{C}$ in summer, but surface sediment temperatures can reach $-1^{\circ} \mathrm{C}$ and $32^{\circ} \mathrm{C}$, respectively (de Montaudouin et al. 2003). Sediment was a medium sand (median grain size: $350 \mu \mathrm{m}$; silt-clay content: 1 to $5 \%$; organic matter content: 0.4 to $1.5 \%$ ) (de Montaudouin 1996). The cockle population was located at $1.9 \mathrm{~m}$ above mean low water level.

The second study site (La Canelette) was in the eastern part of the lagoon. This station is characterised by a salinity range of 22 to 32 psu (Bouchet 1968), water temperature fluctuating seasonally between $1^{\circ} \mathrm{C}$ and $28^{\circ} \mathrm{C}$, and sediment temperature of -3 to $43^{\circ} \mathrm{C}$ at the surface (de Montaudouin et al. 2003). This sandflat

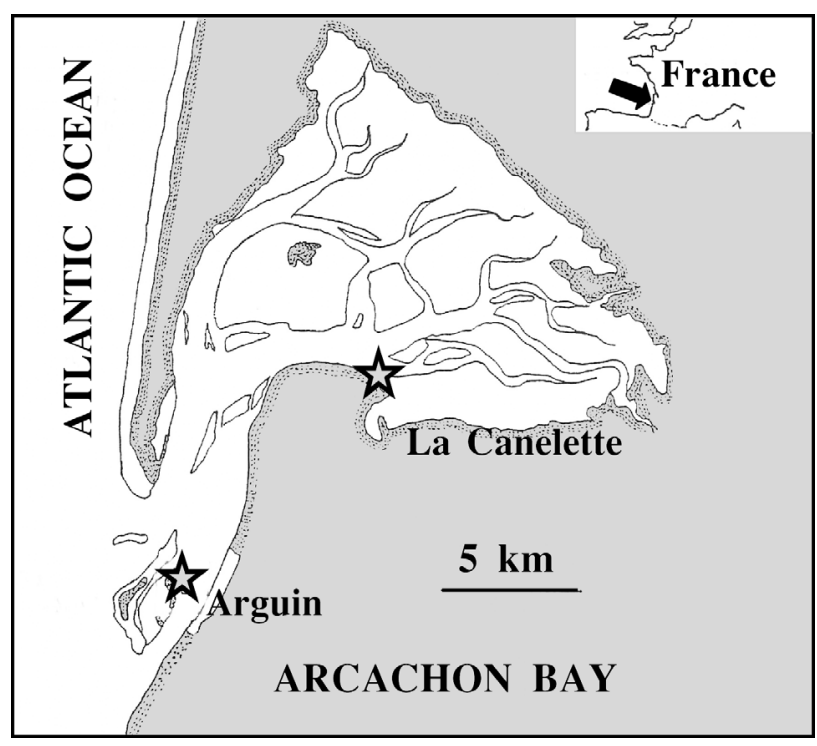

Fig. 1. La Canelette and Banc d'Arguin in Arcachon Bay 
is located near Arcachon harbour. Sediment was a medium sand (median grain size: $225 \mu \mathrm{m}$ ) with $5.5 \%$ silt-clay and $0.7 \%$ organic matter. The sampling area was situated at $2.7 \mathrm{~m}$ above mean low water level.

Study organisms. Parasite: Like many digeneans, $\mathrm{Hi}$ masthla quissetensis Miller \& Northup has several larval stages and requires several hosts to complete its life cycle (Fig. 2). Adult worms, most often located in the alimentary tract of the final host (larid birds), release eggs with bird faeces. The free-swimming ciliated miracidium leaves the egg and penetrates the first intermediate host, the gastropod Nassarius reticulatus (L.) in Arcachon Bay. Asexual reproduction within the snail leads to the formation of thousands of cercariae that emerge from the snail and actively swim for 6 to $12 \mathrm{~h}$ (Stunkard 1938). Cercariae penetrate the second intermediate host, Cerastoderma edule, by the inhalant siphon. They encyst in the bivalve foot and become metacercariae. After being ingested with the cockle by the final bird host, metacercariae develop into adult worms.

Host: The edible cockle Cerastoderma edule (L.) is one of the most common intertidal bivalves on the sandy shores and estuaries of the NE Atlantic. It ranges from the Barents Sea to the Moroccan coast (Tebble 1966). Located in the upper centimetres of the sediment (Zwarts \& Wanink 1989), cockles can emerge from the sediment due to sediment erosion (Richardson et al. 1993), oxygen depletion (Wegeberg \& Jensen 1999), or pathology (Bowers et al. 1996, Desclaux et al. 2002). Like other suspension feeders, cockles are parasitized mostly through their ventilatory activity (Wegeberg et al. 1999).

Field transplant experiments. Transplant experiments were carried out in 1999 and 2000 at La Canelette. In both years, cockles were collected in February at Arguin, where infection by Himasthla quissetensis was low (Desclaux et al. 2002). The oldest and most

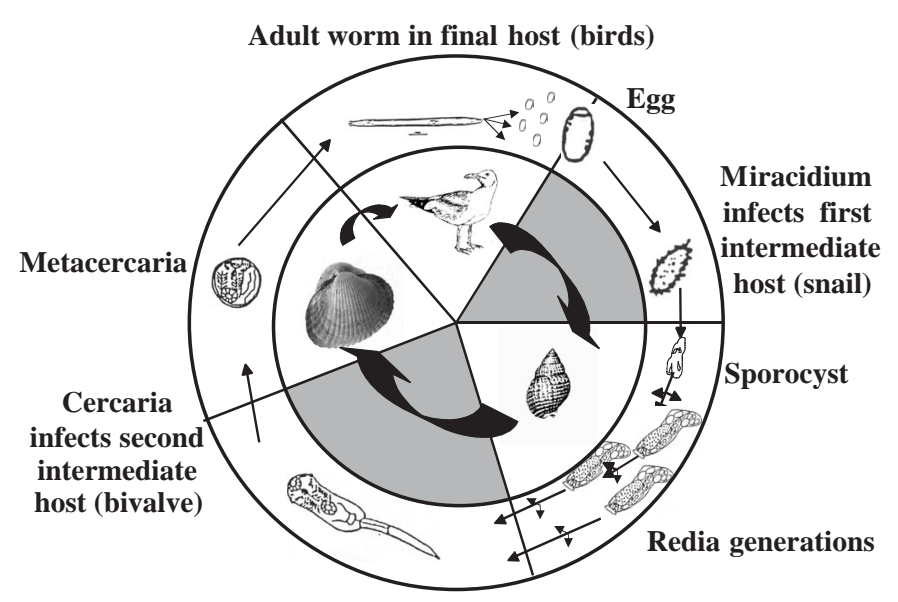

Fig. 2. Himasthla quissetensis. Life cycle of the digenean abundant cockle cohort was selected in order to maximise the number of infected cockles at the destination site, larger individuals being infected at higher rates. Each year, a total of 1500 cockles were measured and their shells were marked with a spot of paint. At the beginning of both years, shell length (mean $\pm \mathrm{SE}$ : $25.5 \pm 0.3 \mathrm{~mm}$ ) was similar $(\mathrm{p}>0.05)$. The day following collection, marked cockles were deployed at La Canelette, on a $1 \times 6 \mathrm{~m}$ area, i.e. at an abundance of 250 ind. $\mathrm{m}^{-2}$. Such an abundance was consistent with natural abundances observed previously in Arcachon Bay and, more particularly, at Arguin (de Montaudouin 1996). Every month for at least 11 mo, 20 marked cockles were collected and dissected, and the mean abundance of infection by $H$. quissetensis metacercariae was calculated. Abundance of infection was defined as the number of individuals of a particular parasite species per host examined (infected + uninfected) (Margolis et al. 1982, Bush et al. 1997).

Water temperature, which is considered to be the main factor inducing emergence of Himasthla spp. cercariae (Craig 1975), was measured at both origin and transplant sites with a Prosensor Thermic Tidbit probe $\left(\right.$ period $=15 \mathrm{~min}$, precision $=0.4^{\circ} \mathrm{C}$ ). Data were collected regularly with an infrared optic shuttle and transferred to a PC with BoxCar Pro (Version 3.51 for Windows) software.

For each transplant year, monthly mean abundances of infection by Himasthla quissetensis were compared using a 1-way ANOVA and Tukey's test (Sokal \& Rohlf 1981). Prior to the analyses, data normality was assumed and homogeneity of variance was tested using Cochran's test.

Host and parasite dynamics survey. Cockles were sampled monthly at La Canelette and Arguin from October 1997 to October 2001. Six $0.25 \mathrm{~m}^{2}$ quadrats penetrating $10 \mathrm{~cm}$ deep into the sediment were taken randomly and washed on a $1 \mathrm{~mm}$ mesh sieve. If necessary, more individuals were collected by hand to obtain at least 20 specimens for dissection. Cockles were counted and measured with callipers to the nearest $0.1 \mathrm{~mm}$ to establish abundance and size structure of the populations. Due to the generally low abundance of cockles, cohorts were identified by comparing individual sizes to population growth curves previously established for these sites (G. Bachelet unpubl. data) or by counting shell rings.

A total of 3984 cockles were dissected (1513 from Arguin and 2471 from La Canelette). They were examined for parasites by squashing the flesh between 2 large glass slides and observing it in transmitted light with a stereomicroscope. Metacercariae species were identified and counted in order to determine the prevalence of the different parasite species. However, only the dominant species, Himasthla quissetensis, was 
quantified (as numbers of metacercariae per cockle) in this study. Metacercariae of $H$. quissetensis were identified by the presence of 31 collar spines around the oral sucker and by the cyst diameter (140 to $190 \mu \mathrm{m}$; Stunkard 1938, Prévot 1974). Abundance of infection by this digenean was calculated. Empty cysts were also counted and were assumed to be dead metacercariae of $H$. quissetensis when their diameter was similar. Dead metacercariae were not included in $H$. quissetensis mean abundance.

Data analysis. Sample size (i.e. the number of cockles per cohort) was frequently small, especially for the oldest cohorts. Therefore, mean monthly data (cockle shell length and abundance, abundance of live and dead Himasthla quissetensis) at each site were first calculated for each age class, then pooled over the $4 \mathrm{yr}$ of monitoring, thereby erasing the inter-annual variability and creating a theoretical cockle cohort. For example, infection pattern of Year 1 cockles was the mean of the first-year infection pattern of cockles recruited from 1998 to 2001. For each age class of the theoretical cohort, the number of individuals taken into account was $\geq 25$. During the non-infection period (i.e. from October/November to April/May according to transplant experiments, see 'Results'), a decrease in parasite abundance was observed. Assuming that this decrease resulted from the mortality of the most heavily infected cockles, we estimated the number of cockles that should have disappeared. In October/ November, when $H$. quissetensis abundance was the highest, a matrix was constructed with the $H$. quissetensis abundance of each cockle from each age class considered in the mean abundance calculation. Then the cockle with the highest $H$. quissetensis abundance was taken off, simulating the death of this cockle and thus obtaining a new, lower mean abundance. This was sequentially reiterated until the infection abundance in the mean abundance calculation reached the value for the following April/May.

Multiple linear regression analyses were performed for both sites between October/November and April/ May, i.e. during the period with no new cockle infection by Himasthla quissetensis. In these analyses the dependent variable was the mean number of $H$. quissetensis metacercariae in cockles; the independent variables were the period of the year (i.e. months), the cockle abundance in each cohort, the mean cockle shell length, the mean abundance of dead $H$. quissetensis metacercariae in cockles and water temperature. According to Scherrer (1984), multiple linear regression must be done between a dependent variable and independent variables, with no correlation among independent variables. At Arguin, cockle shell length was correlated $(\mathrm{p}<0.05)$ with cockle abundance $(\mathrm{R}=-0.71)$ and age $(\mathrm{R}=0.98)$, and cockle abundance was correlated with cockle age
( $\mathrm{R}=-0.76)$ (Pearson's correlation coefficient). Therefore, H. quissetensis abundance (dependent variable) was tested with months, dead cyst abundance, cockle shell length and water temperature. At La Canelette, cockle shell length was correlated $(\mathrm{p}<0.05)$ with the mean abundance of dead cysts $(\mathrm{R}=0.48)$ and cockle age $(\mathrm{R}=$ 0.99), and the dead cyst abundance was correlated with cockle age $(\mathrm{R}=0.44)$. In this station, $H$. quissetensis abundance was tested with months, cockle abundance, cockle shell length and water temperature.

\section{RESULTS}

\section{Transplant experiments}

During the $2 \mathrm{yr}$ of transplantation, experiments showed that cockles were not infected by Himasthla quissetensis during the colder period (Fig. 3). Infection began in May/June, when temperature reached about $17^{\circ} \mathrm{C}$ (Fig. 4). Mean parasite abundance increased progressively and reached a plateau of infection (about 120 and 90 metacercariae cockle ${ }^{-1}$ in 1999 and 2000, respectively) by October/November, when temperature decreased to ca. $12^{\circ} \mathrm{C}$ (Fig. 4). There was no significant difference in the abundance of infection of cockles by $H$. quissetensis during the colder period, i.e. between February and May in both transplant experiments, between October and January for the 1999 experiment and between October and April for the 2000 experiment ( $p>0.05$ ) (Fig. 3).

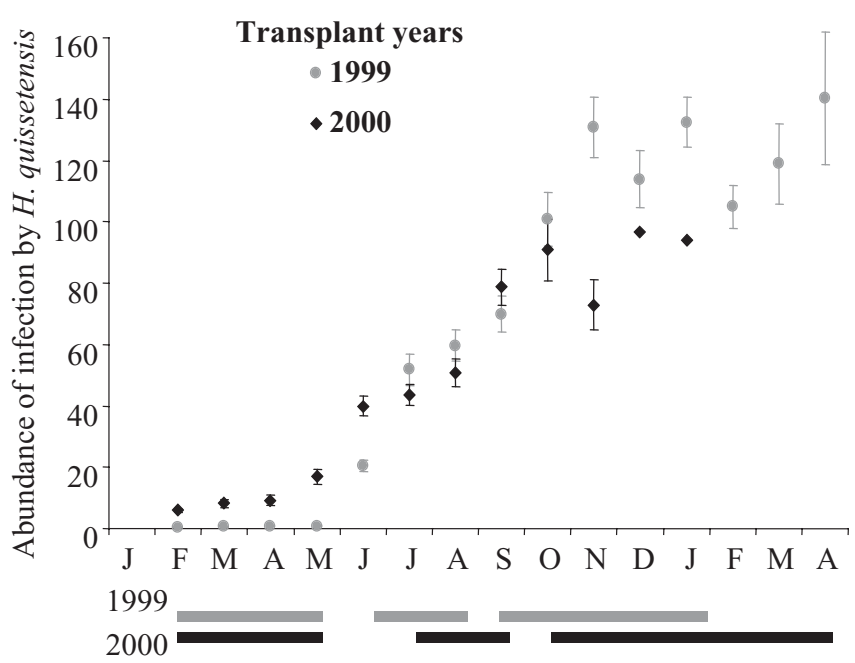

Fig. 3. Cerastoderma edule. Mean $( \pm \mathrm{SE})$ monthly abundance of infection (number of metacercariae per host) by Himasthla quissetensis in adult cockles transplanted from Arguin (as less heavily parasitized animals) to La Canelette. Horizontal bars connect means that are not significantly different (Tukey's tests; $\mathrm{p}>0.05$ ) 
Fig. 4. Seawater temperature variations from 1997 to 2002 at both study sites. Horizontal arrows show water temperatures of 17 and $12^{\circ} \mathrm{C}$. Vertical arrows indicate the time when water temperature exceeded $17^{\circ} \mathrm{C}$ (i.e. water temperature required to involve a digenean infection) every year

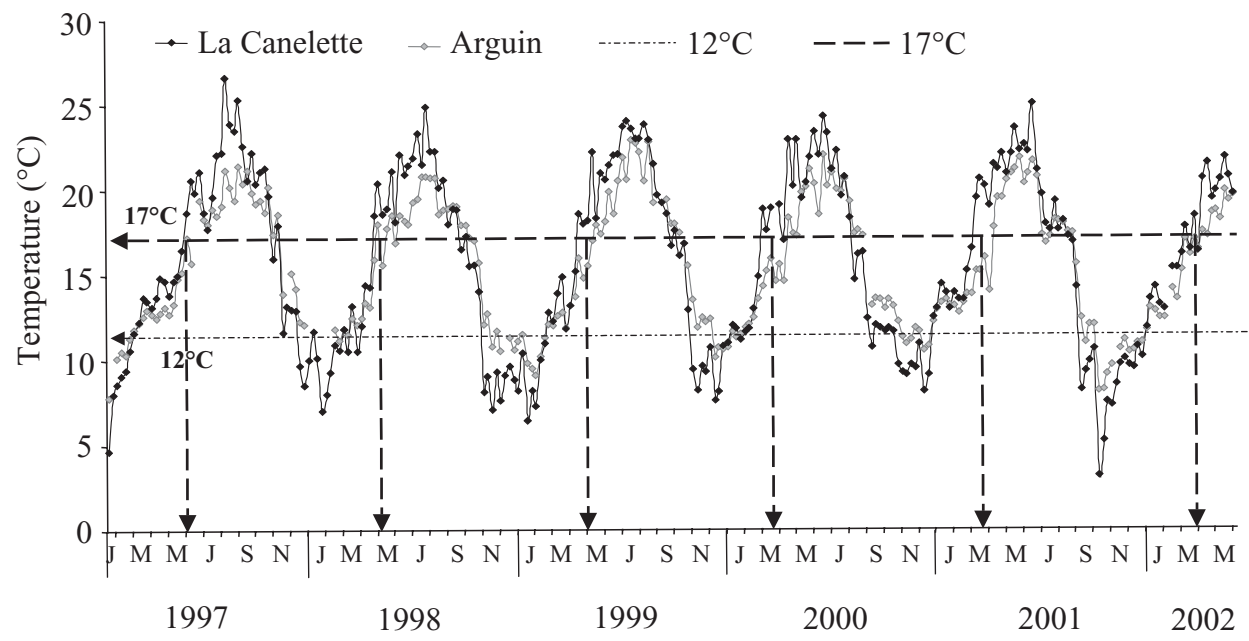

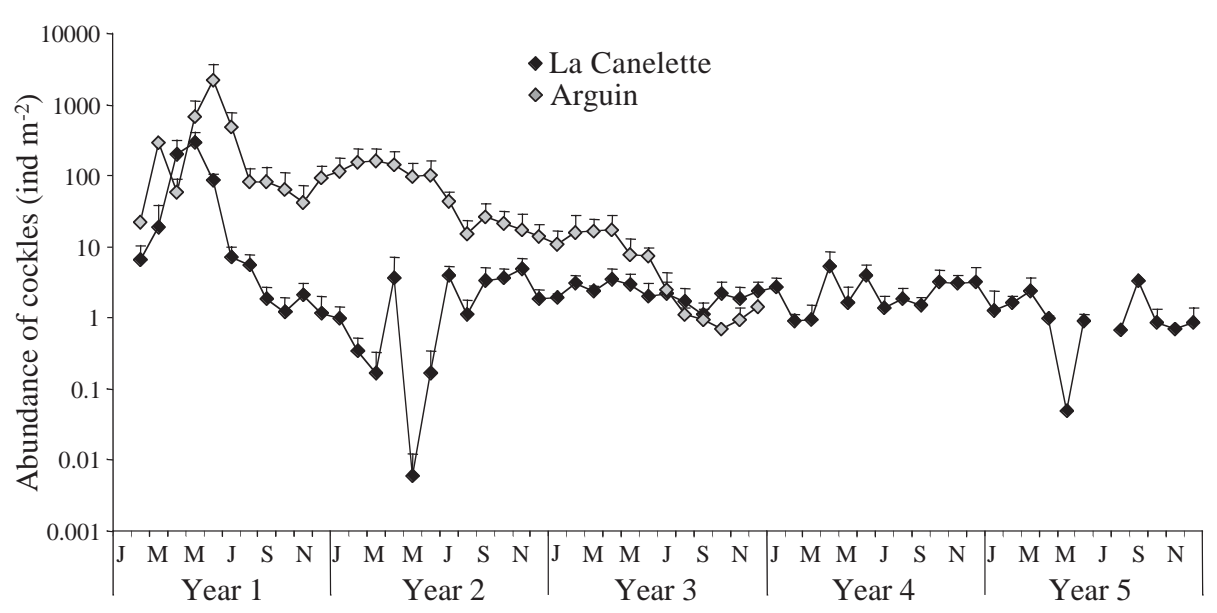

Fig. 5. Cerastoderma edule. Mean abundance (ind. $\mathrm{m}^{-2}+\mathrm{SE}$ ) from recruitment to death of a theoretical cohort (see 'Data analysis' for explanation) in the 2 sampling stations

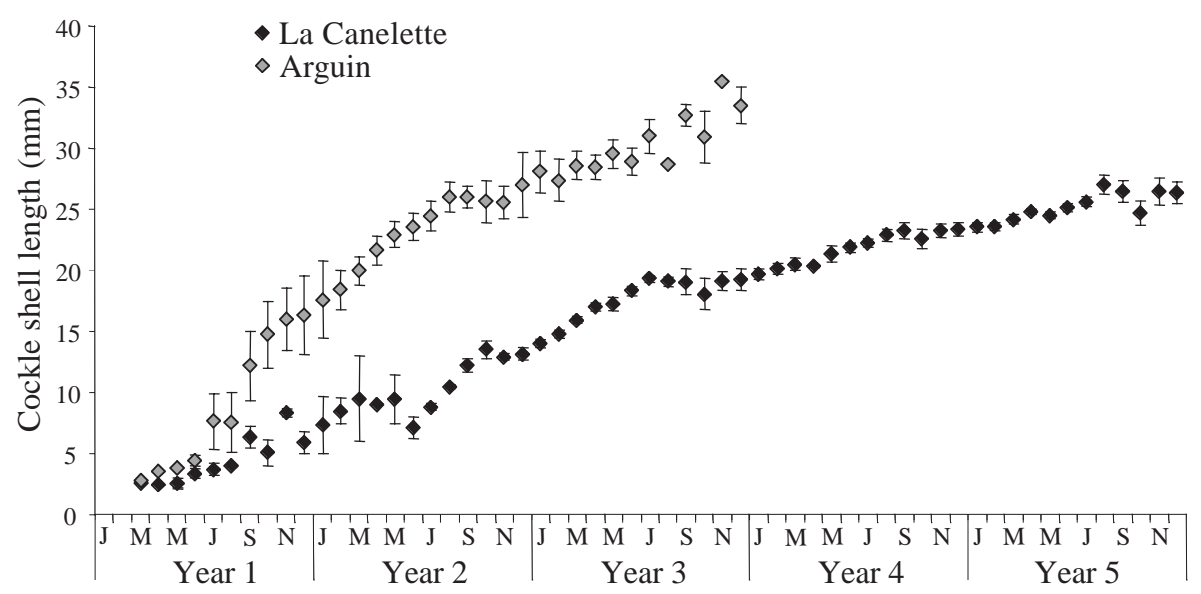

Fig. 6. Cerastoderma edule. Mean shell length $(\mathrm{mm}, \pm \mathrm{SE})$ from recruitment to death of a theoretical cohort at the 2 sampling stations

\section{Cockle population dynamics}

Cockle populations at the 2 sites differed greatly in mean abundance (Fig. 5) and individual growth rate (Fig. 6). At Arguin, cockle recruitment began in April to May, and the maximum abundance of juveniles occurred in June, with $>2000$ ind. $\mathrm{m}^{-2}$. In June of the second year, mean cockle shell length was $23.6 \mathrm{~mm}$ and mean abundance was about 100 ind. $\mathrm{m}^{-2}$ (i.e. $95 \%$ mortality during the first year of life). In June of their third (and last) year, cockles had a shell length of $28.9 \mathrm{~mm}$ and an abundance $<10$ ind. $\mathrm{m}^{-2}$ (i.e. $90 \%$ mortality during the second year of life).

At La Canelette, the cockle population was much smaller. The peak of juveniles occurred in May with only 285 ind. $\mathrm{m}^{-2}$. Within 3 to $4 \mathrm{mo}$, the abundance fell to $2-5$ ind. $\mathrm{m}^{-2}$ ( 98\% mortality), then remained nearly constant. Longevity at La Canelette can be estimated at 4.5 vs $2.5 \mathrm{yr}$ at Arguin. Growth rate was much lower at La Canelette than at Arguin: a size of $20 \mathrm{~mm}$ was reached after about 3 and $1 \mathrm{yr}$, respectively. The mean maximum shell length was also lower at La Canelette $(26 \mathrm{~mm})$ than at Arguin (34 mm). 


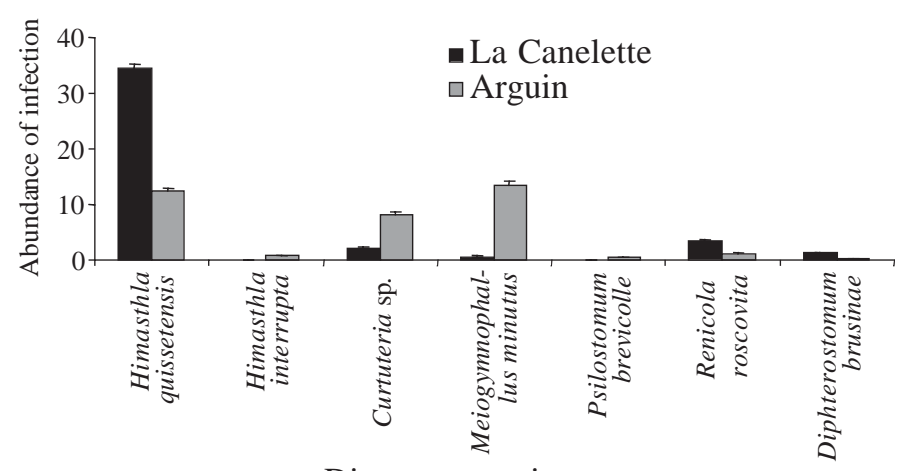

Digenean species

Fig. 7. Cerastoderma edule. Mean (+SE) abundance of infection by different digeneans during the $4 \mathrm{yr}$ survey at La Canelette and Arguin. Another species, Himasthla elongata, occurred at Arguin, with a mean abundance of infection of $<0.03$

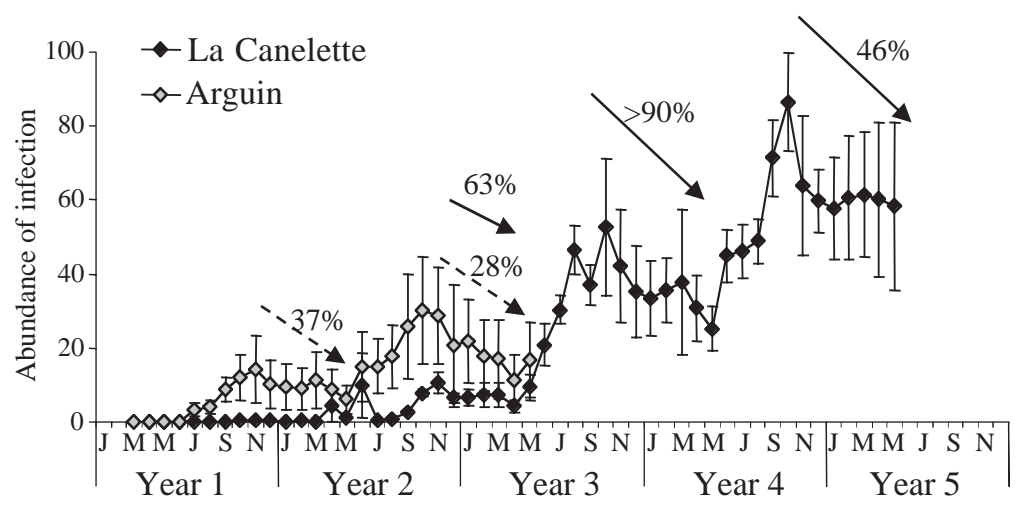

Fig. 8. Cerastoderma edule. Mean $( \pm \mathrm{SE})$ abundance of infection by Himasthla quissetensis at Arguin and La Canelette from recruitment to death of a theoretical cohort. Arrows: cockle mortality at Arguin (hatched lines) and at La Canelette (solid lines)

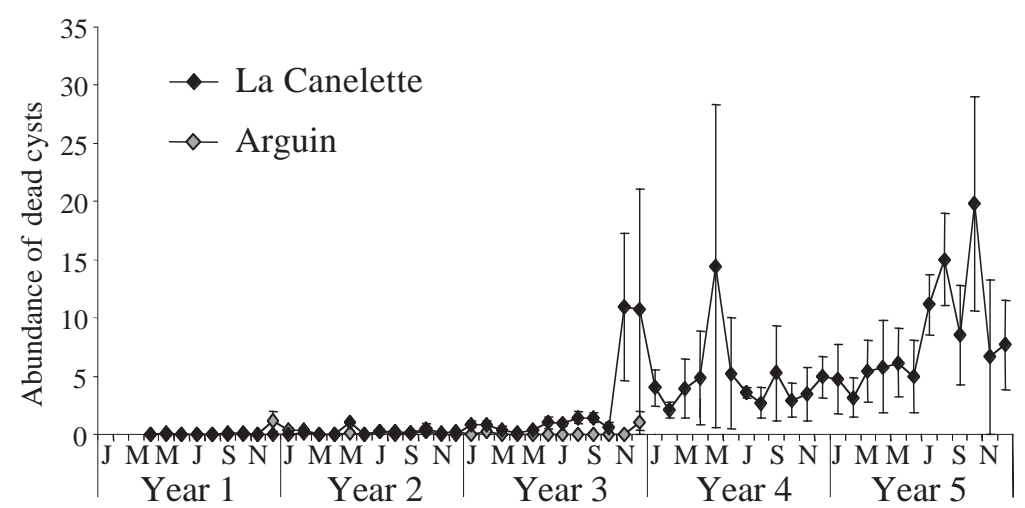

Fig. 9. Cerastoderma edule. Mean $( \pm \mathrm{SE})$ abundance of dead cysts of Himasthla quissetensis per cockle, from recruitment to death of a theoretical cohort

\section{Himasthla quissetensis infection phenology}

During the 4 yr survey, 8 digenean species in metacercarial stage were identified in cockles (Fig. 7). In both stations, Himasthla quissetensis dominated in abundance, with a mean of 34 and 12 metacercariae cockle $^{-1}$ at La Canelette and Arguin, respectively; the mean number of metacercariae from other digenean species did not exceed 15 cockle $^{-1}$ (Fig. 7).

At both stations, the general pattern of infection was similar, with an increase of Himasthla quissetensis abundance during the warmer period and a decrease during the colder period (Fig. 8) as observed in the transplant experiment (Fig. 3). However, parasite infection intensity differed between stations. At Arguin, the mean abundance of $H$. quissetensis per cockle (HA) was negatively correlated with time $(M$, in months, with October $=1$ to May $=8)(p<0.001)$ and positively correlated with cockle length $(L$, in $\mathrm{mm})(\mathrm{p}<0.001)$ (Table 1), and the model (Eq. 1):

$$
H A=-2.79 M+1.03 L-0.29
$$

explained $93 \%$ of the winter decrease in $H$. quissetensis abundance. At La Canelette, the mean abundance of $H$. quissetensis was negatively correlated with time $(\mathrm{p}<0.001)$ and positively correlated with cockle shell length $(\mathrm{p}<$ $0.001)$ and seawater temperature $\left(T\right.$, in $\left.{ }^{\circ} \mathrm{C}\right)(\mathrm{p}<$ 0.01) (Table 1); this model (Eq. 2):

$$
H A=-5.38 M+5.85 L+1.30 T-66.97
$$

explained $97 \%$ of the decrease in $H$. quissetensis abundance between October/November and April/May.

At Arguin, infection of juveniles began in July (Fig. 8), when cockle length was $7.6 \mathrm{~mm}$ and seawater temperature was $19^{\circ} \mathrm{C}$. Mean Himasthla quissetensis abundance (HA) progressively increased and reached a maximum in November $\left(H A=15\right.$ metacercariae cockle ${ }^{-1}$, $L=16 \mathrm{~mm}, T=13.5^{\circ} \mathrm{C}$ ). During the first winter, $H A$ decreased to 8 metacercariae cockle ${ }^{-1}$ by the following May $\left(L=23 \mathrm{~mm}, T=16.2^{\circ} \mathrm{C}\right)$. This decrease corresponded to a cockle mortality rate of $37 \%$ between November and May, during which the number of dead metacercariae remained low (mean of 0.26 dead cysts cockle ${ }^{-1}$ ) and constant (Fig. 9). Parasite recruitment began again in May of Year 2 and reached 32 metacercariae cockle ${ }^{-1}$ in October $(L=25.6 \mathrm{~mm}$, $T=17.3^{\circ} \mathrm{C}$ ). The mean abundance of infection decreased until April of Year 3 ( $H A=15$ metacercariae cockle ${ }^{-1}, L=28.5 \mathrm{~mm}, T=12.4^{\circ} \mathrm{C}$ ). The corresponding mortality was $28 \%$ (no increase in dead metacercariae; Fig. 9). After 

abundance (number of metacercariae per cockle) (dependent variable) and the independent variables: period of the year (Months 1 to 8: October to May), number of dead cysts, cockle shell length $(\mathrm{mm})$ and seawater temperature $\left({ }^{\circ} \mathrm{C}\right)$ at Arguin; and period of the year, cockle abundance (ind. $\mathrm{m}^{-2}$ ), cockle shell length and seawater temperature at La Canelette

\begin{tabular}{|lcccccc|}
\hline & Constant & Months & $\begin{array}{c}\text { Dead } \\
\text { cysts }\end{array}$ & $\begin{array}{c}\text { Shell } \\
\text { length }\end{array}$ & $\begin{array}{c}\text { Temper- } \\
\text { ature }\end{array}$ & \\
\hline Arguin & & & & & & \\
$\quad$ Estimate & -0.29 & -2.79 & -0.03 & 1.03 & 0.40 & \\
$\mathrm{SE}$ & 5.50 & 0.32 & 0.05 & 0.14 & 0.33 & 2.322 \\
$\mathrm{p}$ & 0.959 & 0.000 & 0.620 & 0.000 & 0.265 & 0.000 \\
$\mathrm{R}^{2}$ & & & & & & 0.934 \\
La Canelette & & & & & & \\
Estimate & -66.97 & -5.38 & -0.76 & 5.85 & 1.30 & \\
$\mathrm{SE}$ & 7.74 & 0.53 & 0.95 & 0.32 & 0.40 & 4.960 \\
$\mathrm{p}$ & 0.000 & 0.000 & 0.438 & 0.000 & 0.005 & 0.000 \\
$\mathrm{R}^{2}$ & & & & & & 0.970 \\
\hline
\end{tabular}

Table 1. Himasthla quissetensis. Multiple linear regressions between mean

significant when the abundance of metacercariae per cockle reached 10 and at a cockle size of $13.5 \mathrm{~mm}$, while at Arguin these figures were 32 metacercariae and $25.6 \mathrm{~mm}$, respectively. Therefore, the critical number of metacercariae per cockle inducing mortality at the population scale is likely to depend on an interaction between cockle length and environmental characteristics.

Autopsies confirmed that cockles sheltered up to 8 digenean species, as previously observed by Lauckner (1971), de Montaudouin et al. (2000) and Desclaux (2003). Echinostomatidae are the most prevalent digeneans in cockles from Arcachon Bay, especially the 31-collar-spine Himasthla quissetensis

May of Year 3, the number of cockles was insufficient to calculate mortality rates.

At La Canelette, infection began only in April of Year 2 (Fig. 8) ( $\left.L=9.5 \mathrm{~mm}, T=14.2^{\circ} \mathrm{C}\right)$ and increased slowly until November $\left(H A=10, L=13.5 \mathrm{~mm}, T=11.6^{\circ} \mathrm{C}\right)$. Then, the mean abundance of infection decreased to 4 metacercariae cockle ${ }^{-1}$ by April $(L=15.9 \mathrm{~mm}, T=$ $12.6^{\circ} \mathrm{C}$ ), while there was no increase in dead metacercariae (Fig. 9). This HA decrease corresponded to $63 \%$ cockle mortality between November and April. The mean Himasthla quissetensis abundance increased between May $\left(T=17.5^{\circ} \mathrm{C}\right)$ and October $(H A=53, L=$ $19 \mathrm{~mm}, T=16.4^{\circ} \mathrm{C}$ ) of Year 3 , then decreased again until May $\left(H A=31, L=20.5 \mathrm{~mm}, T=13.6^{\circ} \mathrm{C}\right)$, corresponding to $>90 \%$ cockle mortality. Infection of cockles increased again until October to 80 metacercariae cockle $^{-1}$. During Year 4, mortalities were $90 \%$ of the cockle population. Dead metacercariae abundance was higher, but not sufficient to explain this $90 \%$ mortality. Older cockles (in Year 5) were infected by $>50$ metacercariae cockle ${ }^{-1}$ in October. In the next winter, abundance of $H$. quissetensis decreased again; during this last period, the number of dead metacercariae did not increase, and the estimate of cockle mortality was $46 \%$.

\section{DISCUSSION}

This study demonstrated that the digenean Himasthla quissetensis may induce significant mortality in cockle populations. These parasite-induced cockle mortalities were positively correlated with time during the cold season. However, the number of metacercariae beyond which cockle mortality became significant was not assessed. At La Canelette, mortality was
Miller \& Northup (erroneously considered $H$. continua Loos-Frank by de Montaudouin et al. 2000). H. quissetensis metacercariae have been observed in Cerastoderma edule from Arcachon Bay by Desclaux et al. (2002) (0 to 220 metacercariae cockle ${ }^{-1}$ at La Canelette vs 0 to 60 metacercariae cockle ${ }^{-1}$ at Arguin) and from the Ria de Aveiro by Russell-Pinto (1993) (mean prevalence $=59 \%$ ), as well as in C. glaucum from the Mediterranean by Prévot (1974) (22 metacercariae cockle ${ }^{-1}$ ).

Infection of the second intermediate host by Himasthla quissetensis cercariae usually occurred in the warmest period of the year (Prévot 1974, Russell-Pinto 1993). The temperature of maximal cercariae emission from the first intermediate host varies, however, between taxonomic families and even between populations of the same species (Prévot 1974, Lauckner 1983). Our transplant experiments showed that $H$. quissetensis cercariae infected cockles during the warmest months (i.e. from May to October) and that no infection occurred during the coldest season (i.e. from November to April). These results are consistent with Desclaux (2003), who experimentally demonstrated that emission of $H$. quissetensis cercariae occurred between 17 and $23^{\circ} \mathrm{C}$. During both years in our transplant experiments, infection started when water temperature reached $17^{\circ} \mathrm{C}$ (May) and stopped at $12^{\circ} \mathrm{C}$ (November). The duration of cercariae infection at our transplant site was slightly longer (6 mo) than the duration observed by Prévot (1974) in the Mediterranean (4 to $5 \mathrm{mo}$ ). According to Prévot (1974), cercaria shedding is irregular and depends on the activity of the first intermediate host. Nevertheless, the latter is different in the Mediterranean and Atlantic (Cyclope neritea and Nassarius reticulatus, respectively), which could partly explain differences in cercaria shedding between both locations. 
Besides temperature and parasite presence, cockle size is another major factor in infection patterns. At Arguin, infection occurred when shell length reached $8 \mathrm{~mm}$, i.e. during the first summer. In contrast, at La Canelette, growth rate was much lower, mainly due to the high tidal level of the population (de Montaudouin 1996): an $8 \mathrm{~mm}$ shell length was not reached before the first winter, and, consequently, infection only could start during the second summer. Cockle growth is therefore a determinant factor in infection kinetics. The size/infection relationship is species-dependent. The infection threshold with Himasthla quissetensis, observed in situ, at $8 \mathrm{~mm}$ cockle shell length was similar to that obtained experimentally by de Montaudouin et al. (unpubl. data) with this parasite species, but different from the threshold obtained with other Himasthla species (Jensen et al. 1999, Wegeberg et al. 1999). Therefore, the absence of metacercariae found in cockles $<8 \mathrm{~mm}$ would rather result from an impossibility for juveniles to be infected than from the immediate mortality of newly infected juveniles, as suggested by Lauckner (1987).

Infection patterns at both study sites were consistent with transplant experiments. Cockle infection always occurred during the warmest season, i.e. from May to October/November. The intensity of infection increased with shell length, the largest cockles being the most infected. Such a phenomenon has been observed in other parasite-host systems, e.g. in fish (Kennedy 1984). This is particularly obvious at La Canelette, where an average of 10 metacercariae was found in $14 \mathrm{~mm}$ cockles at the end of the second summer, and 49 more were found at the end of the third summer, when cockles reached $19 \mathrm{~mm}$ in size. The largest cockles ventilated more (André et al. 1993, Riisgård 2001) and consequently inhaled more cercariae (de Montaudouin et al. 1998). Another explanation would be that larger cockles, being older, were exposed to parasites for a longer period, thereby accumulating more parasites. The intensity of infection at the same cockle age was higher at Arguin than at La Canelette. This was merely due to environmental differences and cockle growth. At Arguin, cockle length at a given age was larger than at La Canelette and immersion duration was longer (ca. 1.3×), both factors increasing the probability of infection success.

The transplant experiment demonstrated that no cockle infection occurred from October/November to April/May. Concurrently, the in situ survey at both stations revealed a significant decrease in the mean number of Himasthla quissetensis metacercariae (i.e. live cysts) in cockles during the same period. The decrease of the mean parasite abundance in a cockle cohort can be due to: (1) immigration of the less heavily infected cockles or emigration of highly parasitized cockles, (2) the death of metacercariae in cockles (i.e. increase of empty cysts), or (3) the death of the most heavily infected cockles. Hypothesis 1 can be excluded because of the low locomotive capacity in adult or subadult cockles and the sheltered habitat at both study sites. At Arguin, the number of empty cysts was always very low, with a mean of 0.3 cysts cockle ${ }^{-1}$ (i.e. $1.7 \%$ of the total number of metacercariae [live + dead]), and not correlated with the decrease in $H$. quissetensis abundance. At La Canelette, the mean number of empty cysts was higher (5 cysts cockle $^{-1}$, i.e. $9.2 \%$ of the total number of metacercariae), but did not show any seasonal trend; in particular, it did not increase during the cold season. Consequently, Hypothesis 2, that decrease of the mean parasite abundance in cockles is due to the death of metacercariae, can be rejected. Therefore, this decrease in parasite abundance was due to parasite-dependent mortality (Hypothesis 3). Such a dome-shaped curve of parasite abundance (or prevalence) in its host in relation with cohort age has already been utilised as a parasitedependent mortality index in other host-parasite systems, mainly with first intermediate hosts (Bowers 1969, Schmidt \& Fried 1997, Rantanen et al. 1998, Watters 1998, de Montaudouin et al. 2003).

In our study, the contribution of parasites to cockle population mortality depended on the sampling site. At Arguin, total cockle mortality during the first year of benthic life (April to April) was 93\%, with no significant involvement of parasites. At this age and size, cockle mortality could be attributed mainly to epibenthic predation by birds, crabs, shrimps and fish (Hancock \& Urquhart 1965, Sanchez-Salazar et al. 1987a, 1987b, Griffith 1990). During Year 2, the mortality of survivors from the Year 1 was $85 \%$, with $28 \%$ due to parasitism by $H$. quissetensis. Desclaux et al. (2002) showed that $<2 \%$ out of $28 \%$ could be related to a 'favourization' process, i.e. the parasite inducing the emergence of cockles and facilitating predation by a final host. At La Canelette, the scenario was different. Recruitment was much lower than at Arguin, and total cockle mortality reached almost $100 \%$ in Year 1, with no parasite contribution because cockles were too small for infection to occur. At this station cockle growth rate was low, and individuals remained for a long time within a size range in which they were particularly vulnerable to crab predation (SanchezSalazar et al. 1987b). The few remaining survivors were characterised by a relatively low growth rate and high longevity. The total cockle mortality per year was very low, but mostly due (directly or indirectly through predation) to parasites after the first year. At La Canelette, the favourization contribution to mortality was even smaller than at Arguin (Desclaux et al. 2002).

This study gives, for the first time, a precise phenology of cockle infection by an echinostomatid digenean and illustrates the interaction between temperature 
and host growth rate. This is also the first time that the contribution of digenean parasites to the mortality of their second intermediate host has been quantified in the wild. It shows that the role of parasites in cockle mortality was very different between sites. However, parasite-dependent mortality, as assessed in the present study, was underestimated, because it is not yet possible to detect this mortality during the infection period, i.e. during half of the year. Nevertheless, some further questions remain unanswered, such as how metacercariae induce mortality in cockles. Previous studies have shown that metacercariae produce several detrimental effects on their molluscan hosts, e.g. (1) the amputation of bivalve siphons (Maillard 1976); (2) the alteration of clam valve edges, which then remain open and make the host more sensitive to desiccation or predation (Bartoli 1974); (3) the secretion of ligament proteins under the umbo, preventing closing of the valves (Bowers et al. 1996); (4) an immunodepression of parasitized organisms, making them more susceptible to stress (oxygen depletion, pollution, heavy metals, osmotic and/or thermic stress) (Lauckner 1983, Jensen et al. 1999); or (5) the reduction of burrowing performance (Thomas \& Poulin 1998, Mouritsen 2004). In the case of Himasthlinae, metacercariae also could induce harmful tissue damage such as: (1) destruction of muscle fibres, as cercariae pass through muscle layers situated beneath the epidermis of the viscero-pedal mass (Jensen et al. 1999); (2) tissue lysis caused by cercarial enzymes (Lauckner 1983); (3) loss of body fluids through penetration holes, which interfere with the cockle's filtration capacity (Wegeberg 1998); (4) haemocytes and fibrous tissue accumulation around the cyst secreted by the parasite (Jensen et al. 1999); (5) distortion of cells and hypertrophy of the infected organs (Lauckner 1983); and (6) an association with a bacterial load, increasing mortality rates (Blanchet et al. 2003).

Acknowledgements. We are grateful to I. Kisielewski for having initiated the transplant experiments, $\mathrm{H}$. Blanchet for his help during field sampling, whatever the weather was like, and for his pleasant laboratory company. C. Audemard, K. Hudson and R. Carnegie for help in correcting the English text, IFREMER Arcachon for providing ARCHYD water temperature data, J. J. Boubert and the SEPANSO for access to the Banc d'Arguin. We also wish to thank 4 anonymous reviewers for their helpful comments on earlier versions of the manuscript. This study is a contribution to the French Programme on Coastal Environment (PNEC-Contract IFREMER/CNRS-UMR5805 No. 00/1/14073).

\section{LITERATURE CITED}

Anderson RM, Gordon DM (1982) Processes influencing the distribution of parasite numbers within host populations, with special emphasis on parasite-induced host mortalities. Parasitology 85:373-398
André C, Jonsson PR, Lindegarth M (1993) Predation on settling bivalve larvae by benthic suspension feeders: the role of hydrodynamics and larval behaviour. Mar Ecol Prog Ser 97:183-192

Auby I, Trut G, d'Amico F, Beliaeff B (1999) Réseau hydrologique du Bassin d'Arcachon-Synthèse des résultats 1988-1997. IFREMER Rep DEL/AR/RST/99-09, Arcachon

Bartoli P (1974) Recherche sur les Gymnophallidae F. N. Morozov, 1955 (Digenea), parasites d'oiseaux des côtes de Camargue: systématique, biologie et écologie. $\mathrm{PhD}$ thesis, University of Aix-Marseille

Bartoli P (1976) Modification de la croissance et du comportement de Venerupis aurea parasité par Gymnophallus fossarum P. Bartoli, 1965 (Trematoda, Digenea). Haliotis 7: $23-28$

Blanchet H, Raymond N, de Montaudouin X, Capdepuy M, Bachelet G (2003) Effects of digenean trematodes and heterotrophic bacteria on mortality and burying capability of the common cockle Cerastoderma edule (L.). J Exp Mar Biol Ecol 293:89-105

Bouchet JM (1968) Etude océanographique des chenaux $\mathrm{du}$ bassin d'Arcachon. Habilitation thesis, University of Bordeaux 1

Bower SM (1992) Diseases and parasites of mussels. In: Gosling E (ed) The mussel Mytilus: ecology, physiology, genetics and culture. Elsevier, Amsterdam, p 543-563

Bowers EA (1969) Cercaria bucephalopsis haimeana (LacazeDuthiers, 1854) (Digenea: Bucephalidae) in the cockle, Cardium edule L. in South Wales. J Nat Hist 3:409-422

Bowers EA, Bartoli P, Russell-Pinto F, James BL (1996) The metacercariae of sibling species of Meiogymnophallus, including M. rebecqui comb. nov. (Digenea: Gymnophallidae), and their effects on closely related Cerastoderma host species (Mollusca: Bivalvia). Parasitol Res 82:505-510

Bush AO, Lafferty KD, Lotz JM, Shostak AW (1997) Parasitology meets ecology on its own terms: Margolis et al. revisited. J Parasitol 83:575-583

Combes C (1991) Ethological aspects of parasite transmission. Am Nat 138:866-880

Combes C (2001) Parasitism. The ecology and evolution of intimate interactions. University of Chicago Press, Chicago

Craig LH (1975) Himasthla quissetensis and Lepocreadium setiferoides: emergence patterns from their molluscan host, Nassarius obsoletus. Exp Parasitol 38:56-63

Deltreil JP, His E (1970) Sur la présence d'une cercaire de trématode chez Cardium edule L. dans le Bassin d'Arcachon. Rev Trav Inst Pech Marit 34:1225-1232

de Montaudouin X (1996) Factors involved in growth plasticity of cockles Cerastoderma edule (L.) identified by field survey and transplant experiments. J Sea Res 36:251-265

de Montaudouin X, Wegeberg AM, Jensen KT, Sauriau PG (1998) Infection characteristics of Himasthla elongata cercaria in cockles as a function of water current. Dis Aquat Org 34:63-70

de Montaudouin X, Kisielewski I, Bachelet G, Desclaux C (2000) A census of macroparasites in an intertidal bivalve community, Arcachon Bay, France. Oceanol Acta 23:453-468

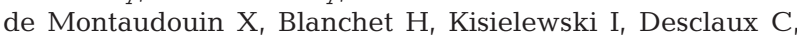
Bachelet G (2003) Digenean trematodes moderately alter Hydrobia ulvae population structure. J Mar Biol Assoc UK 83:297-305

Desclaux C (2003) Interactions hôtes-parasites: diversité, mécanismes d'infestation et impact des trématodes digènes sur les coques Cerastoderma edule (mollusque bivalve) en milieu lagunaire macrotidal. $\mathrm{PhD}$ thesis, University of Bordeaux 1

Desclaux C, de Montaudouin X, Bachelet G (2002) Cockle 
emergence at the sediment surface: 'favourization' mechanism by digenean parasites? Dis Aquat Org 52:137-149

Fried B, Idris N, Ohsawa T (1995) Experimental infection of juvenile Biomphalaria glabrata with cercariae of Echinostoma trivolvis. J Parasitol 81:308-310

Griffith CL (1990) Spatial gradients in predation pressure and their influence on the dynamics of two littoral bivalve populations. In: Morton B (ed) The bivalvia. Proceedings of a memorial symposium in honour of Sir Charles Maurice Yonge. Hong Kong University Press, Hong Kong, p 321-332

Hancock DA, Urquhart AE (1965) The determination of natural mortality and its causes in an exploited population of cockles (Cardium edule L.). Fish Invest II 24:1-40

Holmes JC, Bethel WH (1972) Modification of intermediate host behaviour by parasites. Zool J Linn Soc 51:123-149

Jensen KT, Fernández Castro N, Bachelet G (1999) Infectivity of Himasthla spp. (Trematoda) in cockle (Cerastoderma edule) spat. J Mar Biol Assoc UK 79:265-271

Jonsson PR, André C (1992) Mass mortality of the bivalve Cerastoderma edule on the Swedish west coast caused by infestation with the digenean trematode Cercaria cerastodermae I. Ophelia 36:151-157

Kennedy CR (1984) The use of frequency distributions in an attempt to detect host mortality induced by infections of diplostomatid cercariae. Parasitology 89:209-220

Lauckner G (1971) Zur Trematodenfauna der Herzmuscheln Cardium edule und Cardium lamarcki. Helgol Wiss Meeresunters 22:377-400

Lauckner G (1983) Diseases of mollusca: bivalvia. In: Kinne $\mathrm{O}$ (ed) Diseases of marine animals. Biologische Anstalt Helgoland, Hamburg, p 477-961

Lauckner G (1984a) Impact of trematode parasitism on the fauna of a North Sea tidal flat. Helgol Meeresunters 37: 185-199

Lauckner G (1984b) Brackish-water submergence of the common periwinkle, Littorina littorea, and its digenean parasites in the Baltic Sea and in the Kattegat. Helgol Meeresunters 37:177-184

Lauckner G (1987) Effects of parasites on juvenile Wadden Sea invertebrates. In: Tougaard S, Asbirk S (eds) Proc 5th Int Wadden Sea Symp. National Forest and Nature Agency and Museum of Fisheries and Shipping, Esbjerg, p 103-121

Lester RJG (1984) A review of methods for estimating mortality due to parasites in wild fish populations. Helgol Meeresunters 37:53-64

Maillard C (1976) Distomatoses de poissons en milieu lagunaire. $\mathrm{PhD}$ thesis, University of Montpellier

Margolis L, Esch GW, Holmes JC, Kuris AM, Schad GA (1982) The use of ecological terms in parasitology (report of an ad hoc committee of the American Society of Parasitologists). J Parasitol 68:131-133

Moore J, Gotelli NJ (1990) A phylogenetic perspective on the evolution of altered host behaviours: a critical look at the manipulation hypothesis. In: Barnard CJ, Behnke JM (eds) Parasitism and host behaviours. Taylor \& Francis, London, p 193-233

Mouritsen KN (2004) Intertidal facilitation and indirect effects: causes and consequences of crawling in the New Zealand cockle. Mar Ecol Prog Ser 271:207-220

Mouritsen KN, Jensen KT (1997) Parasite transmission between soft-bottom invertebrates: temperature mediated infection rates and mortality in Corophium volutator. Mar Ecol Prog Ser 151:123-134

Poulin R (1995) 'Adaptative' changes in the behaviour of parasitized animals: a critical review. Int J Parasitol 25: 1371-1383

Poulin R, Hecker K, Thomas F (1998) Hosts manipulated by one parasite incur additional costs from infection by another parasite. J Parasitol 84:1050-1052

Prévot G (1974) Recherches sur le cycle biologique et l'écologie de quelques trématodes nouveaux parasites de Larus argentatus michaellis Naumann dans le Midi de la France. $\mathrm{PhD}$ thesis, University of Aix-Marseille

Rantanen JT, Valtonen ET, Holopainen IJ (1998) Digenean parasites of the bivalve mollusc Pisidium amnicum in a small river in eastern Finland. Dis Aquat Org 33:201-208

Richardson CA, Ibarrola I, Ingham RJ (1993) Emergence pattern and spatial distribution of the common cockle Cerastoderma edule. Mar Ecol Prog Ser 99:71-81

Riisgård HU (2001) On measurement of filtration rates in bivalves - the stony road to reliable data: review and interpretation. Mar Ecol Prog Ser 211:275-291

Russell-Pinto F (1993) Espécies de digenea que infectam Cerastoderma edule (n.v. berbigão) em Portugal. Caracterização da resposta do hospedeiro à infestação. $\mathrm{PhD}$ thesis, University of Porto

Sanchez-Salazar ME, Griffith CL, Seed R (1987a) The interactive roles of predation and tidal elevation in structuring populations of the edible cockle, Cerastoderma edule. Estuar Coast Shelf Sci 25:245-260

Sanchez-Salazar ME, Griffith CL, Seed R (1987b) The effect of size and temperature on the predation of cockles Cerastoderma edule (L.) by the shore crab Carcinus maenas (L.). J Exp Mar Biol Ecol 111:181-193

Scherrer B (1984) Biostatistique. Gaëtan Morin Editeur, Montréal

Schmidt KA, Fried B (1997) Prevalence of larval trematodes in Heliosoma trivolvis (Gastropoda) from a farm pond in Northampton County, Pennsylvania with special emphasis on Echinostoma trivolvis (Trematoda) cercariae. J Helminthol Soc Wash 64:157-159

Sokal RR, Rohlf FJ (1981) Biometry. WH Freeman, San Francisco

Stunkard HW (1938) The morphology and life cycle of the trematode Himasthla quissetensis (Miller \& Northup, 1926). Biol Bull (Woods Hole) 75:145-164

Tebble N (1966) British bivalve seashells. British Museum of National History, London

Thomas F, Poulin R (1998) Manipulation of a mollusc by a trophically transmitted parasite: convergent evolution or phylogenetic inheritance? Parasitology 116:431-436

Watters G (1998) Prevalences of parasitized and hyperparasitized crabs near South Georgia. Mar Ecol Prog Ser 170: 215-229

Wegeberg AM (1998) Digene trematoders (Echinostomatidae) infektionsøkologi og effekt pa Cerastoderma edule. MS thesis, University of Aarhus

Wegeberg AM, Jensen KT (1999) Reduced survivorship of Himasthla (Trematoda, Digenea)-infected cockles (Cerastoderma edule) exposed to oxygen depletion. J Sea Res 42:325-331

Wegeberg AM, de Montaudouin X, Jensen KT (1999) Effect of intermediate host size (Cerastoderma edule) on infectivity of cercariae of three Himasthla species (Echinostomatidae, Trematoda). J Exp Mar Biol Ecol 238:259-269

Wilson K, Bjørnstad ON, Dobson AP, Merler S, Poglayen G, Randolph SE, Read AF, Skorping A (2002) Heterogeneities in macroparasite infections: patterns and processes. In: Hudson PJ, Rizzoli A, Grenfell BT, Heesterbeek H, Dobson AP (eds) The ecology of wildlife diseases. Oxford University Press, Oxford, p 6-44

Zwarts L, Wanink J (1989) Siphon size and burying depth in deposit- and suspension-feeding benthic bivalves. Mar Biol 100:227-240 